\title{
腹腔鏡下腎孟形成術後に腎孟内に迷入した金属クリップに

\author{
結石形成を来たした一例
}

\author{
北里大学医学部泌尿器学教室（主任：馬場志郎教授） \\ 南田諭岩村 正嗣宋成浩 笹本 治子 \\ 石川 弥 黒坂 眞二 藤田 哲夫 馬場 志郎
}

\section{SPONTANEOUS MIGRATION OF A METAL CLIP INTO RENAL PELVIS \\ AFTER LAPAROSCOPIC PYELOPLASTY : A CASE REPORT}

Satoru Minamida, Masatsugu Iwamura, Shigehiro Soh, Haruko Sasamoto,

Wataru Ishikawa, Shinji Kurosaka, Tetsuo Fujita and Shiro Baba

From the Department of Urology Kitasato University School of Medicine

Migration of surgical materials into the urinary tract is very rare. We present a case of spontaneous migration of a metal clip into renal pelvis after laparoscopic pyeloplasty.

A 44-year-old woman who had a long history of multiple sclerosis presented with symptomatic left hydronephrosis due to ureteropelvic junction (UPJ) obstruction. Since antegrade endopyelotomy was unsuccessful, the patient underwent laparoscopic Anderson-Hynes pyeloplasty. The UPJ was wrapped with thick inflammatory tissue and a crossing vessel that firmly adhered to the UPJ was found and dissected. Metal clips were used for hemostasis. Although the hydronephrosis was improved and flank pain was completely dissolved, a stone was identified in the pelvis 22 months after the surgery. The stone was formed around a metal clip that had been possibly migrated into the renal pelvis. Transureteral lithotripsy was performed using an 8F ureterofiberscope and a clip was removed.

Key words : laparoscopic pyeloplasty, clip, stone

\begin{abstract}
要旨 : 症例は 44 歳女性. 既往歴に多発性硬化症がありステロイド剤を服用していた. 経過中に左腎孟尿 管移行部 (UPJ) 狭窄による水腎症を診断され, Double-Pigtail Stent (D-P ステント)を留置されていた. UPJ の狭窄に対しホルミウム-YAG レーザーによる Endopyelotomyを施行したが, 再狭窄を認めた為 に, Anderson-Hynes 法による腹腔鏡下腎孟形成術を施行した，術中 UPJ 腹側を横断する交差血管を含 む索状物を認めたため, 金属性血管用クリップを用いてクリッピング後に切断した.

術後経過は良好で，水腎症の改善を認めていたが, 術後 1 年 10 力月目の KUB にて左腎孟内結石を認 め，術中に使用した金属クリップが腎孟内に迷入した為に生じた腎孟結石と診断した？そのため軟性尿 管鏡による経尿道的尿管砕石術（TUL：Transurethral ureterolithotripsy）を施行，尿管鉗子を使用し金 属クリップを摘出した.

クリップの迷入による腎孟内結石の形成は極めて稀であり, 我々が調べ得た限りでは本例が一例目で ある. 若干の文献的考察を加えて報告する.

キーワード：腹腔鏡下腎孟形成術, クリップ, 結石
\end{abstract}

緒 言

腹腔鏡下手術において，金属製クリップによる血管 処理は一般的に行われている手法であり，腹胿鏡下胆
囊摘出手術でのクリップの総胆管等への迷入は報告例 がある.

今回我々は腹腔鏡下腎孟形成術後の腎孟内にクリッ 
プが迷入し結石を形成した症例を経験したので報告す る.

\section{症例}

患者 : 44 歳, 女性.

主訴：左腎孟内結石.

既往歴：多発性硬化症.

家族歴：特記事項なし.

現病歴：1993 年頃より排尿困難を認めた為当科受 診. Cystometography にて Hypoactive bladder め, 多発性硬化症を伴う神経因性膀胱と診断. Clean intermittent catheterization（CIC）を指導した，超音 波検查抢よび経静脈的腎孟造影 (IVP)を施行したとこ ろ左の水腎症を認めた. 腹部 CT 上 UPJ は腎盂の腹側 で 2 本の交义血管により压排されており腎孟尿管移行 部 (UPJ)の狭窄と診断した。開腹による腎孟形成術を 勧めるも, 多発性硬化症の病状が不安定であった為, Double-Pigtail Stent (D-P ステント) 留置とし， 3 カ月 に1回の交換にて経過観察となった.

その後多発性硬化症の悪化により他病院へ転院. そ の間の D-P ステント交換は施行できず， 2 年以上の長 期にわたり放置された結果 D-P ステント両側端に石 灰化を形成した，そのため経皮的腎砕石術 (PNL：Percutaneous nephrolithotripsy）を施行し，同時にUPJ の狭窄に対しホルミウム-YAGレーザーによるEn- dopyelotomy を施行し，D-P ステントを抜去した． その後再度UPJの狭窄認めた為にAndersonHynes 法による腹胿鏡下腎孟形成術を試行した。腎孟 尿管壁は著明に肥厚し周囲組織と強固に癒着しており 剥離に難渋した。術中 UPJ 腹側を横断する交差血管を 含む索状物を 2 力所認めたため, 可能な限り剥離し, 金属性血管用クリップを用いてクリッピング後に切断 した（切断部の両断端にクリップがかかるようにク リッピングした).また癒着剥離中に血管が含まれると 思われた索状物に対しても同様にクリッピングを施行 した，腎盎内にD-P ステントを留置し，吸収糸を用い て腎盂を結節縫合し手術終了となった。手術時間は 310 分，出血量は術野の尿を含み $230 \mathrm{ml}$ であった。術 中, 術後に特記すべき合併症は認めず, D-P ステントは 術後 4 週間で拔去した.

術後 6 力月目の IVP 所見（図 1）では，腎盂尿管移 行部の狭窄は改善を認めた。 その後, 術後 1 年 10 力月 目の KUB (図 2) で左腎孟 (下腎杯) に直径 $1 \mathrm{~cm}$ 大の 結石を認めた。

検查成績：血液一般,生化学検查では異常を認めず。 尿検查：RBC 15 20/HPF，WBC 30 50/HPF.

治療経過：自然排石を期待して経過観察するも結石 は徐々に増大したＩVPを施行（図 3) したところ，術 後 6 カ月目の IVP (図 1) では腎孟外に存在した金属ク

図 2 術後 1 年 10 力月目 KUB (左腎部拡大画像) 左腎孟内に直径 $1 \mathrm{~cm}$ 大の結石を認めた。

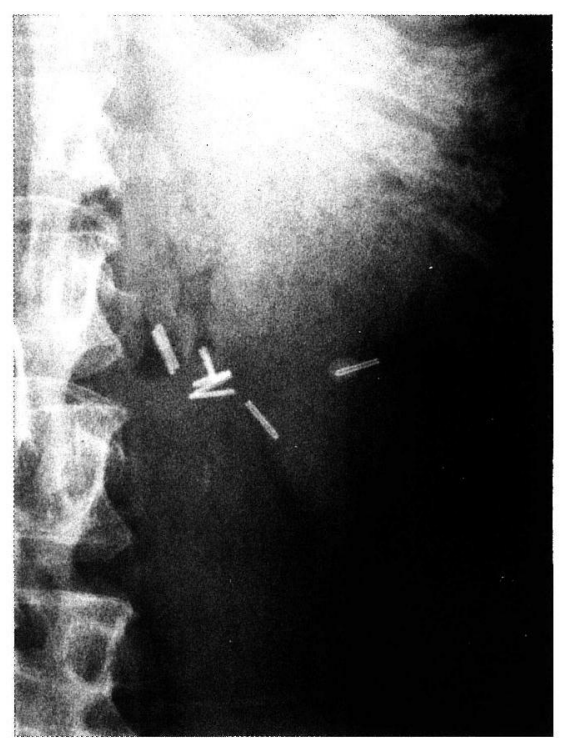


図 3 術後 2 年目 IVP (左腎部拡大画像) 図 1 と比較して，金属クリップが腎孟内に迷入してお り，金属クリップの周围に結石形成を認める.

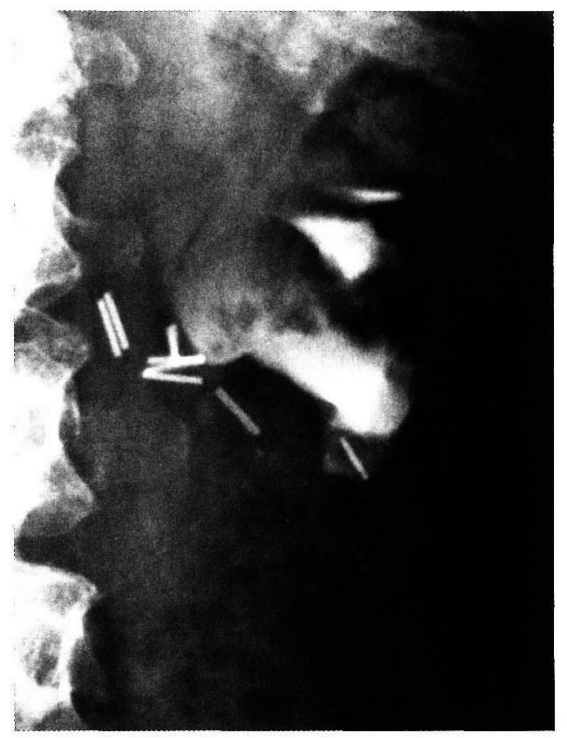

リップが腎孟内に迷入して扔り，このクリップ周囲に 結石を形成したものと考えられた。

そのため $8 \mathrm{Fr}$ の軟性尿管鏡を使用し TUL を施行し た，腎孟内を観察したところ，下腎杯にクリップを中 心に形成された結石が確認した。電気水圧砕石器 （EHL : electrohydrauric lithotripsy）にて砕石し, ク リップは鉗子にて摘出した.

\section{考察}

腹腔鏡下手術でのクリップによる血管処理は一般的 に広く行われる手技である，腹腔鏡下胆囊摘出術後の 胆管内へのクリップ迷入の報告は数例あるが，尿路内 への迷入の報告は無い.

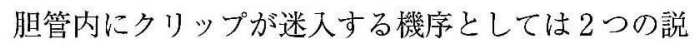
が提示されて抢り，吻合部からの迷入説と壁内に陥没 することによる迷入説がある. 吻合部からの迷入説と しては奥山らは, 胆道周囲に存在する異物が胆道周囲 の炎症によって胆道内に迷入し，長期停滞することに よって結石を形成すると述べている1). また Raoul ら は, 不完全閉鎖により生じた Biloma が, 胆道管より吸 収される際にクリップも引き込まれる，と述べてい る2). 壁内に陥没することによる迷入説としては，Kitamura らはクリップされた胆囊管が肝臓など周囲組 織に圧排され，総胆管壁内に陥没していき，やがて胆
囊管は壊死に陥り，クリップのみが総胆管内に残ると いう仮説がある゙．今回の腎孟内へのクリップはいず れかの機序が考えられるが，詳細は不明である.

また尿路系へのクリップの迷入は過去に報告例はな いが，異物の膀胱内への迷入は幾つか報告例が存在す る. 膀胱外から人工血管の膀胱内への迷入や ${ }^{4)}$, 胵内か ら子宮内避妊具が膀胱内へ迷入し結石を形成をした報 告例もある ${ }^{5) 6}$. これらの迷入の機序も，クリップの迷 入と同様に長期留置による子宮壁の損傷による炎症や 周辺からの圧迫により異物が膀胱壁内に陌没もしくは 穿孔し迷入したものと考觉られており 、クリップだ けでなく吸収性のない異物の長期留置は他臟器へ迷入 する可能性があると考えられる。

予防法としては吸収性のクリップを使用する, 縫合 部付近では糸を使用する，バイポーラなどを使用する などが考えられるが，吸収性のクリップの迷入や吸収 性のクリップが核となった結石の報告例 ${ }^{788}$, 絹系を核 とする結石の報告例もあり ${ }^{9)}$ ，吻合部付近では吸収糸 やバイポーラの使用が最も良いと考えられる.

初回手術後よりクリップが迷入し, 結石が形成され るまでの期間は本症例では 1 年 10 力月であるが, 腹腔 鏡下胆囊摘出術における結石判明までの期問は術後 1 年未満から 6 年まであり, 平均 3.1 年である ${ }^{103}$.

尿路吻合部近傍でのクリップの使用は極力避けるべ きであり，クリップを使用した場合，迷入する可能性 を考慮し，比較的長期閒の経過観察が必要なことが示 唆される.

\section{結 語}

腹胿鏡下手術において，金属製クリップによる血管 処理は一般的に行われている手法であるが，尿路の縫 合部近傍での使用に際しては尿路内への迷入の危険性 があることを念頭におくべきと思われた.

腹腔鏡下腎孟形成術後に腎孟内に迷入した金属ク リップに結石を形成した一例を経験したので若干の文 献的考察を加え報告した。

\section{文 献}

1）奥山和明, 高橋敏信, 永田松夫, 佐藤 博, 田 紀 克 : 胆摘後形成せる総胆管絹系結石の検討. 胆と 膵, 2,596 - 575,1981 .

2) Raoul JL, Bretagne JF, Siproudhis L, Heresbach D, Campion JP, Gosselin M : Cystic duct clip migration into the common bile duct: A complication of laparoscopic cholecystectomy treated by endoscopic biliary sphincterotomy. Gastrointest Endosc, 38, 608-611, 1992. 
3) Kitamura K, Yamaguchi T, Nakatani H, Ichikawa D, Shimotsuma M, Yamane T, Takahashi T : Why do cystic duct clips migrate into the common bile duct. The LANCET, 346, 965-966, 1995.

4）駒井好信, 漆原正泰, 森本信二, 酒井邦彦 : Stamey 手術に使用された人工血管を核にして発生した膀 胱結石の 1 例. 泌尿器科紀要, 50 (3), 203-205, 2004.

5) Guvel S, Tekin MI, Kilinc F, Peskircioglu L, Ozkardes $\mathrm{H}$ : Bladder stones around a migrated and missed intrauterine contraceptive device. Int $\mathrm{J}$ Urol, 8, 78-79, 2001.

6) Atakan H, Kaplan M, Ertrk E : Intravesical migration of intrauterine device resulting in stone formation. Urology, 60, 911iii-911v, 2002.

7）玉城 哲, 高江洲裕, 武藤良弘, 草野敏臣, 本間周 淳, 野原正史 : 腹腔鏡下胆囊摘除時の胆蓑管断端 吸収性クリップが肝内胆管に迷入した 1 治験例.
胆道, 7,63一67, 1993 .

8) Onghena T, Vereecken L, Van den Dwey K, Van Loon C : Common bile duct foreign body. An unusual case. Surg Laparosc Endosc, 2, 8-10, 1992.

9）佐久間洋一, 竜 崇正, 岡田 正, 今園 修, 趙 明浩, 泉 誠, 具沼 修, 高石 聡, 有田誠司, 山田英夫, 村岡 実, 吉田正実, 高山 亘, 奥山和 明, 阿部恭久, 遠藤正人, 一瀬雅典, 篠原靖志, 福 長 徹, 保元明彦, 児玉多曜, 西郷健一, 落合武徳 : 胆囊管断端の結紮は吸収糸でなければいけない か? 胆と膵, 22 (11), 933-937, 2001 .

10）川口米栄, 八木浩一, 金沢孝満, 中山 洋, 三上 繁, 久保田芳郎 : 胆囊摘出術時のクリップを核と して結石が形成された 1 例. 手術, 57(11), 14231427, 2003.

（2007 年 1 月 25 日受付, 4 月 11 日受理） 